\title{
Volunteer translation and altruism in the context of a nineteenth-century scientific journal
}

DOI:

10.1080/13556509.2012.10799508

\section{Document Version}

Accepted author manuscript

Link to publication record in Manchester Research Explorer

\section{Citation for published version (APA):}

Olohan, M. (2012). Volunteer translation and altruism in the context of a nineteenth-century scientific journal. The Translator, 18(2), 193-215. https://doi.org/10.1080/13556509.2012.10799508

\section{Published in:}

The Translator

\section{Citing this paper}

Please note that where the full-text provided on Manchester Research Explorer is the Author Accepted Manuscript or Proof version this may differ from the final Published version. If citing, it is advised that you check and use the publisher's definitive version.

\section{General rights}

Copyright and moral rights for the publications made accessible in the Research Explorer are retained by the authors and/or other copyright owners and it is a condition of accessing publications that users recognise and abide by the legal requirements associated with these rights.

\section{Takedown policy}

If you believe that this document breaches copyright please refer to the University of Manchester's Takedown Procedures [http://man.ac.uk/04Y6Bo] or contact uml.scholarlycommunications@manchester.ac.uk providing relevant details, so we can investigate your claim.

\section{OPEN ACCESS}




\title{
Accepted Author Manuscript
}

Olohan, Maeve (2012) 'Volunteer Translation and Altruism in the Context of an NineteenthCentury Scientific Journal', The Translator 18(2): 193-215.

\section{Volunteer Translation and Altruism in the Context of a Nineteenth-Century Scientific Journal}

\author{
MAEVE OLOHAN \\ University of Manchester, $U K$
}

\begin{abstract}
This paper constitutes a first attempt to theorize volunteer translation using behavioural economic models of altruism. It applies the notions of pure and impure altruism to the study of a nineteenth-century journal of scientific translations, Scientific Memoirs. Volunteer translating and editing activities were instrumental in ensuring the commercial survival of that periodical over a 15-year period. A range of motivations may be posited for the volunteer work carried out, from the purely altruistic wish to expand scientific knowledge to motivations which could be linked to a sense of satisfaction (warm glow) or enhancement of personal, professional or social standing. Differences can be observed in the utility likely to have been derived from their volunteer activities by men of science and women translators, and an insight is offered into how volunteer contributions were encouraged and managed by the journal's editor, Richard Taylor. By drawing on research on altruism and volunteering undertaken by disciplines other than translation studies, the paper offers a fruitful starting point for further research on volunteer translation and interpreting in both present-day and historical settings.
\end{abstract}

Keywords. Impure altruism, Warm glow, History of scientific translation, Scientific Memoirs, Richard Taylor, Professionalization of translation.

A distinction is sometimes made, as in the theme of this volume, between 'professional' and 'non-professional' or 'amateur' translating and interpreting. Trainers of translators and interpreters aim to prepare students for 'the profession' and therefore devote parts of their curricula to 'professional development' activities, generally reaching some accord on what that entails. However, if comparisons are drawn with professions such as law, medicine or accountancy, the extent to which translating and interpreting can be deemed to have the status 
of profession becomes debatable. ${ }^{1}$ Although some institutional infrastructure has been established for both translator and interpreter education and training in many parts of the world - including professional bodies, codes of conduct, formal education, certification and a recognized knowledge base - the degree of professionalization, measured in this way, varies across national and international contexts. It was, for example, a lack of uniformity of education and certification processes that prompted recent initiatives such as the European Master's in Translation network (2009) and the Optimale project (n.d.) on translator training; both are responses to a perceived need to establish a common, competence-based framework for translator training in Europe, perhaps leading to a common certification process in due course. Moreover, although many professional bodies receive strong support from translators and interpreters, they are often not as powerful as their counterparts in the professions mentioned above, in that they tend not to exert the same degree of influence on practice and practitioners, or on legislation and regulation. Other aspects typical of professional status are present in some countries but completely absent in others; these include, crucially, control of admission to the profession, legal protection of work, and recognized status of practitioners. Thus, the professional status of translators and interpreters appears to be less clear-cut when we benchmark translation and interpreting against other professions. It may be more accurate to refer to an ongoing professionalization of translation and interpreting.

The purpose of this paper is not to pursue this problematic distinction between professional and non-professional activity, however; it focuses instead on the provision of non-remunerated translation work, i.e. on translations by those who do not receive or expect to receive direct monetary reward for time and effort expended. This volunteer activity may be considered typical of 'non-professional' or 'amateur' translation, but it can also be practised by 'professionals', which means that professional status is of less relevance here. Current examples include translation projects with humanitarian aims (e.g. Rosetta Foundation, Kiva, Ashoka); politicized, activist networks (e.g. Babels, Tlaxcala); open source software localization initiatives (e.g. Translation Project) and crowd-sourced localization of social networking websites (e.g. Facebook, Twitter), among others. These activities are often referred to as volunteer translation. Volunteering is variously defined and addressed, depending on the disciplinary context in which it is studied. As Handy et al. (2000:46) argue, it is not a monolithic activity and therefore not easy to define. Wilson (2000:215), from a

\footnotetext{
${ }^{1}$ See Arena and Jeppesen (2010) for a discussion of the process of professionalization in internal auditing; although a rather different sector, it provides a useful point of comparison and contrast with translation and interpreting.
} 
social work perspective for example, defines volunteering broadly as "any activity in which time is given freely to benefit another person, group or organization” before discussing the complexity of differentiating volunteering from other 'helping' and 'prosocial' activities. Likewise, Snyder and Omoto (2008:3) define volunteerism as

freely chosen and deliberate helping activities that extend over time, are engaged in without expectation of reward or other compensation and often through formal organizations, and that are performed on behalf of causes or individuals who desire assistance.

This definition excludes, among other things, care and support of family members, spontaneous responses to emergencies, bystander interventions and helping activities where individuals receive compensation for their efforts. However, it would be likely to include the translation activities mentioned above, since they are usually freely opted for, deliberate activities, often extending over time, performed without expected remuneration or similar compensation, and proffered as services that are sought after or solicited by others.

Economic approaches to volunteering tend to focus on similar key dimensions, i.e. free will, availability of remuneration, formal organization of the activity and proximity to the beneficiaries, but can also be interested in the relationship between the benefits and costs of volunteering, particularly in terms of how benefits and costs influence people's decisions to volunteer and public perceptions of volunteers (Handy et al. 2000:46). Thus, volunteering is studied from a wide range of perspectives, with different approaches rooted in a variety of disciplines, including social psychology and behavioural economics, and with scope for those different perspectives to provide complementary insights. Translation scholars have also begun to study some volunteer activities (Baker 2010, Boéri and Maier 2010, O’Brien and Schäler 2010, Pérez González 2010, Morado Vásquez et al. 2011), but there remains considerable scope to enhance our knowledge and understanding of this under-researched area.

The focus of this paper is on altruism as a conceptual tool for understanding volunteer translation. The approach is based in behavioural economics, a branch of economics that is grounded in the neoclassical approach but seeks to make economic explanations and predictions more realistic by underpinning them with insights from psychology (Camerer and Loewenstein 2004:3). The choice of approach is determined to a large extent by the material being studied. The object of study is a periodical published between 1837 and 1852 which 
was established with the aim of disseminating scientific translations into English, and which, for reasons outlined below, has been described by commentators as "altruistic" (Brock and Meadows 1998:102). My interest lies in how the volunteering of various services, including translation, enabled this publication to come into being, as a commercial venture. In studying the volunteering activities in question from some historical distance and through fragmentary documentary evidence, it is possible to speculate on some motives for and benefits of volunteering in this context, using existing models and studies of economic behaviour. Unlike the treatment of altruism in much of the economics literature, this paper offers no mathematical modelling or experimental data but focuses entirely on the qualitative explanations that underpin modelling and experiments. Section 1 introduces key economic concepts for a discussion of voluntarism and altruism. Section 2 contextualizes the publication of the scientific periodical under scrutiny, and Section 3 focuses on some of its translators. Section 4 then suggests how insights from the study of altruism may be applied to these particular instances of volunteer translation.

\section{Pure and impure altruism, public and private goods}

Economics literature that focuses on examples of giving or volunteering in present-day societies has its origins in Adam Smith's foundational economic thinking. In The Theory of Moral Sentiments (1759), Smith considered sympathy, fairness and the 'impartial spectator' as motivating factors in human behaviour (Ashraf et al. 2005:131-32). Almost a century later, the term 'altruism' came into being (from French 'altruisme', denoting 'living for others'), when Auguste Comte used it in his Système de politique positive (Graham 2004:51). The economic model of 'pure altruism' assumes that people give, for example to a charitable organization, solely to increase the supply of a public good, with no utility accruing to them as givers; the giving is selfless and for the benefit of others. Altruism thus conceived contrasts with egoism. However, Andreoni $(1988,1989,1990)$ has argued for the need to develop a model of altruism that incorporates egoism to account for the fact that giving may also be motivated by other factors, including a sense of duty or fairness or a feeling of guilt, as well as the belief that various private goods or benefits may also accrue to the donor. He introduced the notion of 'impure altruism', positing that one of the utilities that a donor may derive is a sense of satisfaction from giving per se (particularly when there is no benefit to be derived by the donor, as in the case of donating money for famine relief on another continent). Andreoni uses the term 'warm glow' to designate this sense of satisfaction. This 
model of impure altruism accounts for various common patterns of behaviour that are inconsistent with the model of pure altruism. ${ }^{2}$

Impure altruism has been studied quite widely, usually using experimental or survey data and in relation to the giving of money, though the notion has also been applied to blood donation (see, for example, Ferguson et al. 2012). In addition, physiological evidence for the 'warm glow' effect has been found in studies employing magnetic resonance imaging (Moll et al. 2006). The giving of one's time or services, voluntarism, has also been considered in the same way (see, for example, Cappellari et al. 2011). In a purely altruistic model of voluntarism, the volunteer's only concern would be the aggregate level of public good provision, but studies such as Lipford and Yandle (2009) have shown that, just as in the giving of money, other motivational factors can also come into play, suggesting that impure altruism is also present in the case of volunteering. Handy and Mook (2011), for example, note how serving as a volunteer trustee on the board of an organization enhances an individual's social status, while those who volunteer their time to help others in their community may derive a warm glow from the satisfaction of helping and a recognition and sense of superiority of their own positional advantage over those who require their assistance. Handy and Mook also note that other by-products of volunteering in such contexts include improvements in perceived self-efficacy and self-esteem, alongside private benefits to the individual such as training, access to social and professional networks, or an enhanced CV (ibid.:414).

In this paper, the notion of altruism is applied to a commercial context - a scientific journal, entitled Scientific Memoirs, published in Britain in the 19th century. Before proceeding further, it is necessary to clarify the notions of public and private goods. Altruism, whether pure or impure, is understood, as above, in relation to an individual's contribution to public utility, generally expressed as an increase in public goods. A public good is defined as "a good that no consumer can be excluded from using if it is supplied, and for which consumption by one consumer does not reduce the quantity available for consumption by any other" (Black et al. 2009). These two classic conditions of public goods - non-excludability and non-rivalry - are often not fully met in the case of other goods, since consumers can be excluded from consumption by cost. Moreover, heavy simultaneous use of a public good can

\footnotetext{
${ }^{2}$ For example, under the purely altruistic model, government funding of a charitable organization, through taxation (involuntary giving), would be expected to crowd out voluntary giving, since the only important issue to an altruistic person would be whether the charity gets funded or not. However, this complete or perfect substitution of funding does not happen. The fact that people continue to donate means there are other motivations for doing so beyond a desire to see the organization funded.
} 
cause congestion problems for other consumers (as might often be the case, for example, for roads, public parks, swimming pools, libraries, etc.). This means that most public goods are, strictly speaking, 'impure public goods'. Public goods are contrasted with private goods, the category into which most consumer goods fall. A private good is "any good or service which is rivalrous (if used by one individual or firm it is not available to others) and excludable (the owner can costlessly prevent other individuals or firms from consuming it)" (Black et al. 2009).

On the basis of these established definitions one might be inclined to perceive of a scientific periodical produced and sold by a commercial publisher as a private good. However, the knowledge disseminated through a scientific publication may be regarded as something that is non-rivalrous (once supplied, there is zero marginal cost in an additional person benefiting from the knowledge) and generally non-excludable (once supplied, no one can be excluded from enjoying the knowledge). This is the perspective offered by Stiglitz's (1999:309) approach to knowledge; he argues that knowledge is a public good by nature, regardless of the (sometimes significant) costs associated with its transmission. ${ }^{3}$ Stiglitz (ibid.) goes further in designating knowledge as a global public good, alongside four other global public goods: international economic stability, international security (political stability), international environment, and international humanitarian assistance. ${ }^{4}$ As the terms suggest, these are public goods whose benefits are experienced across borders. In Section 4 this understanding of knowledge as a public good will facilitate an examination of pure and impure altruism in relation to Scientific Memoirs and its publication context, as detailed below.

\section{Publication of Scientific Memoirs}

The 19th century in Britain saw science shift from a purely intellectual activity to a practical and social one as well (Knight 1986:9), as it simultaneously became institutionalized, professionalized and increasingly specialized (Inkster 1991:94, Bazerman 1988:154). By the

\footnotetext{
${ }^{3}$ Comparisons might also be made with consumer goods such as fair-trade products or recycled products, described as private goods with a public-good dimension (see, for example, Lusk et al. 2006, Guagnano 2001). Purchasers of these goods accrue private benefits but in doing so (particularly when they have to pay a premium for them) contribute to the public goods of global fair trade or environmental sustainability, and may derive satisfaction from doing so.

${ }^{4}$ Stiglitz relies on a conception of (scientific) knowledge as universal in order to argue that knowledge is a global public good; he is interested in knowledge as something that can be transmitted across geographic and presumably linguistic boundaries. This may be contrasted with social constructivist perspectives of knowledge (see, for example, Latour and Woolgar 1986) which treat it as relative and locally contingent.
} 
end of that century, scientists were much more likely to hold professional appointments in universities and research laboratories, and there were clear divisions of knowledge into many of the specialist areas or disciplines that are familiar today. By contrast, at the start of the century, science was mostly conducted by men of independent means who did not earn their livelihood from it, referred to as 'natural philosophers' or 'men of science'. 5 They encountered each other's work in the journals and meetings of the learned societies which accommodated all established branches of science.

In the 1830s, a London publisher and printer, Richard Taylor, launched a periodical entitled Scientific Memoirs, Selected from the Transactions of Foreign Academies of Science and Learned Societies, and from Foreign Journals. Taylor's aim for this publication was that it would publish translations into English of articles and memoirs written in other languages, thus informing British men of science of the work of their counterparts in other parts of Europe, something which Taylor deemed to be "much needed for the progress and advancement of science in this country" (Taylor 1837b). Five volumes of Scientific Memoirs were produced under Taylor's editorship (Taylor 1837c, 1841b, 1843, 1846, 1852b).

Volumes 1-4 appeared in four parts, while Volume 5 had five parts; these were planned as quarterly publications but generally appeared at longer intervals. Following Taylor's retirement in 1852 due to ill health, the periodical continued as two separate series under new editorship but only one volume appeared in each series.

Taylor was convinced of the utility of Scientific Memoirs, as conceived by him, for the advancement of British science, and received statements of support from many men of science who agreed with him: see, for example, Forbes's (1836) letter to Taylor and the listing, in the preface to Volume 1, of the eminent natural philosophers who had expressed their approval of the endeavour (Taylor 1837b). In spite of this, Volume 1 did not sell sufficient copies to cover its cost of production, and the future of the publication was in some doubt (Taylor 1837b) until Taylor managed to increase sales and subscriptions through various publicity and advertising measures. Taylor (1837a:84) stated that he would continue to publish if he could merely cover his costs; he did not expect or need to make a profit from Scientific Memoirs. ${ }^{6}$ For this reason, Brock and Meadows, who chronicled two centuries of

\footnotetext{
${ }^{5}$ William Whewell coined the term 'scientist' in 1833 to designate and unify scientific endeavour and in an attempt to recognize the potential involvement of women, if principally as popularizers of science and as a target audience for those popularized accounts; however, the term did not enter into general usage until much later in the century (Yeo 1993:110-12).

${ }^{6}$ It should be noted that this periodical was able to withstand the various financial and commercial pressures better than many others because Taylor was the editor of the publication as well as the proprietor of the publishing house, which also did its own printing. In relation to another periodical, Taylor acknowledges that
} 
publishing by the Taylor and Francis house, describe Taylor's publishing of Scientific Memoirs as "altruistic" (Brock and Meadows 1998:102). Much of the translation work done for Scientific Memoirs might have been described in similar terms. The scope and nature of that translation activity is outlined in the next section, leading to a discussion in Section 4 of potential motivations for apparently altruistic behaviour in the translation context.

As a periodical devoted to the publication of scientific translations, Scientific Memoirs was unique in its time, and my ongoing, detailed study of it, on which this paper draws, fulfils numerous functions. Firstly, it responds to calls from historians of science (see, for example, Jardine 2000, Topham 2004) to move beyond the study of the canonical book and to focus on the technicians and processes of scientific publishing. Similar calls to focus less on influential books and more on the production of other documents have also come from scholars of translation history (see, for example, Santoyo 2006), though not specifically with respect to scientific translation. Secondly, the study aims to redress the general lack of consideration of translators in the narratives of scientific progress which often rely on the international exchange of scientific ideas through translation but seldom acknowledge the complexities of the translation activity itself or the agency of the translators, with some exceptions (Montgomery 2000, Gutas 1998, Rashed 2006, Wright 2000, Bennett 2007, and contributions in Olohan and Salama-Carr 2011, among others). Finally, it provides a deeper understanding of the conception of translation and translators in the scientific and publishing spheres of nineteenth-century Britain and offers an insight into how translators carried out their tasks in this context. An important aspect of this is the notion of altruism and voluntarism in publishing translations.

\section{Translations and translators}

The five volumes of Scientific Memoirs contain 3,402 pages or 134 articles, only one of which is not based on a text written in a language other than English. ${ }^{7}$ Of the other 133 papers, 81 papers were translated from German, 46 from French, 4 from Italian and 2 from Swedish. Depending on whether one measures by number of authors, number of pages or

such circumstances were more favourable than was the norm at a time when many scientific periodicals failed (First Report from the Select Committee of the House of Commons on Postage; together with the Minutes of Evidence and Appendix 1838).

${ }^{7}$ This was a short paper, of 8 pages, by Joseph Henry of New Jersey, which was published in Volume 1, Part IV, and was written originally in English. Its inclusion was justified by Taylor in a footnote on the basis that Henry's work had been referred to in a preceding paper (by Schulthess) but was not well known in Britain (Henry 1837:540). 
number of papers, German sources make up $57 \%$ to $60 \%$ of the total translations published in Scientific Memoirs. This inclusion of a larger proportion of German material is not surprising since most men of science in Britain had little proficiency in German, while some, but not all, could read French (Knight 1986:63, 2004:177). The shortest papers consisted of only 2 or 3 pages, often consisting of notes which followed on from other contributions by the same author, while the longest papers, of more than 90 pages, were those of Fresnel and Plateau in Volume 5. Although exact word counts are not available, the average article length can be approximated at 8,000 to 10,000 words.

In order to decide what texts to translate and publish, Taylor solicited and received suggestions from the many men of science with whom he was acquainted through his standing in commercial scientific publishing and his involvement in numerous learned societies. Taylor's correspondence and other sources also indicate that, particularly for later volumes, authors themselves requested that their work be included, sometimes using mutual contacts as intermediaries. In addition, Taylor received recommendations through his son, William Francis, who spent some of this period studying chemistry in Germany. Finally, some translations were donated under the auspices of the British Association for the Advancement of Science, from whom Taylor had sought support for the publication; this source is discussed in more detail below.

Who translated for Scientific Memoirs? In some cases the translator of an article is named in a footnote at the beginning of the text, but in many cases the translator remains anonymous. Through a study of paratexts, notably the editor's prefaces, and Taylor's correspondence, it is possible to match a further set of texts with their translators. From 133 papers in Scientific Memoirs, we can thus identify or posit the translators for approximately two thirds of the papers. As regards texts for which no translator is named, correspondence (Francis 1843) indicates that both Taylor and his daughter Sarah Taylor were involved in translating memoirs from French for Scientific Memoirs. While neither is named as translator on any text, it can be assumed that they were responsible for some of the remaining one third of texts that do not have an attributed translator; however, it is not possible to identify which specific texts they produced. Similarly, Edward Brayley carried out editorial work for Taylor on various publications, ${ }^{8}$ and correspondence shows that he revised translations for Scientific

\footnotetext{
${ }^{8}$ Brayley contributed his editing services for several years to one of the leading scientific periodicals of the time, the Philosophical Magazine, published by Taylor. Brayley was named as co-editor on the reverse of the title page and, for a brief period, on the title page (Brock and Meadows 1998:97).
} 
Memoirs (Brayley 1836); it is plausible that he also translated some texts himself but neither the revision nor the translation work is acknowledged within the publication.

The men who produced translations for Scientific Memoirs services can be divided into two groups. On the one hand, there were those like Brayley, mentioned above, and William Francis, Taylor's son, who received payment for their translations and other work related to the preparation of material for publication, as employees of the company. On the other hand, there were men of science who contributed suggestions for works to be translated but also volunteered their translation and revising services. Examples of scientists volunteering to carry out translation work include Hugh Strickland, who wrote to Taylor twice in 1840 offering to carry out translation, specifically referring to Scientific Memoirs and its value in "bringing foreign scientific matters to the notice of Englishmen" (Strickland 1840). Thomas Richardson provided a translation of a memoir by Bunsen, writing to Taylor: "As I am anxious to see your Scientific Memoirs succeed, I shall have great pleasure in adding my mite" (Richardson 1841). Alfred Hobson also wrote to Taylor to offer his translation services for Scientific Memoirs, specifically for any French memoirs on mathematical subjects. His offer accepted, he proceeded to translate lengthy memoirs by Fresnel, Jamin and Melloni. In offering his services (Hobson 1847), he stated:

Of course I do not make this offer with any view to pecuniary remuneration: if a copy of the original memoir were given as an acknowledgement, I should consider it amply sufficient. My object is to aid, if possible in the continuation of the 'Memoirs' which is I think a work of very great importance

Similar offers of assistance were proffered to Taylor for checking or revising translations. John Richardson, for example, wrote in 1845 suggesting work by Müller as a candidate for translation. When a translation had been completed Richardson indicated that he was willing to revise it, but stated that he would make suggestions rather than alterations, "for I should like to know what liberties I may venture to take with the proof without offending the translator Dr Griffiths" (Richardson 1846). His letter suggests that he had no sight of the original German text, but was familiar with other work by Müller and could therefore make judgements about terminology and taxonomy. He asked for his name not to be referenced in the paper since his assistance was of "so light character", but he was "very desirous of lending [his] aid as the German is not so accessible to the English naturalist" (ibid.). 
Three women can be identified among those who gave their translation services to Scientific Memoirs. Women in early nineteenth-century Britain who were interested in participating in scientific activities had fewer ways of doing so than men. They did not have the opportunity to present their own scientific work to the Royal Society until the end of the century, and could not become Fellows of the Royal Society until 1945 (Haines 2001, Fara 2006). ${ }^{9}$ Alongside illustration and popularization, translation was an accepted way for women to contribute to scientific endeavour. As Knight (2004:177) points out, while men had to struggle with Latin, educated women were free to study a range of other subjects, including modern foreign languages. They thus acquired the linguistic proficiency that their male counterparts often lacked, and this gave them an important role in "sustaining the international scientific community by making classic works known across language barriers" (Knight 2004:178). One view of women in Victorian Britain was that they lacked creative ability and were therefore best suited to activities involving mechanical reproduction rather than invention or innovation; this perspective facilitated women's roles as popularizers of science (Winter 1998:207), ${ }^{10}$ and perhaps also as translators. Knight (2007:422) notes that "of many translators, especially the women among them, we know too little". Healy (2004) also stresses the need for research into women translators of science.

One of the women translators for Scientific Memoirs was Richard Taylor's daughter, Sarah, as mentioned above. She is reported as having been well educated, as having remained unmarried, and as having spent her life as her father's housekeeper (Brock and Meadows 1998:37). We know little more about her translation activities, and her input to Scientific Memoirs is recorded through mentions in letters only. By contrast, Ada Lovelace's translation for Scientific Memoirs enjoys a higher profile, and not only because Ada was the daughter of Lord Byron. Although her translator's notes added to a paper by Menabrea about Charles Babbage's Analytical Engine are simply signed “A.A.L.”, her work on the translation can be traced through detailed and frequent correspondence between her and Babbage. Furthermore, both the translator's notes and her correspondence with Babbage have been studied by historians of computing (Fuegi and Francis 2003). Lovelace's notes were three times longer

\footnotetext{
${ }^{9}$ At the time of writing, $5.5 \%$ of the 1,361 Royal Society's Fellows are women (Royal Society n.d.) and discussion on the invisibility of women's contributions to science continues to have relevance today (Shields 2010).

${ }^{10}$ Winter (1998:207) points out that this view is reflected in Mary Somerville's assessment of her own contribution, where she insisted that she had not made any original scientific discoveries, and had intelligence but not genius, the latter allegedly not being granted to women. Alternative representations of women saw them as "untrustworthy purveyors of knowledge because their imaginations were too powerful" (ibid.).
} 
than the original text and are credited with developing applications of Babbage's work that extended beyond his own contribution. They were her only published work.

The third woman volunteer translator for Scientific Memoirs was Elizabeth Sabine. Sabine's name appears on only one of the texts in Scientific Memoirs ("translated by Mrs. Sabine"), while the others bear a mere acknowledgement in Taylor's prefaces that they were "communicated by Lieut-Colonel Sabine", her husband. The reason these translations are mentioned in the prefaces at all is that they were donated to Taylor by the British Association for the Advancement of Science. As noted above, when Taylor was not assured of sales for the first volume, he requested assistance at the 1838 annual meeting of the Association. A committee was then set up, chaired by Edward Sabine, and charged with procuring translations of foreign memoirs, with funds at its disposal to do so. In spite of the funding, only one translation was paid for from the fund (in addition to various illustration plates). The committee's support was more evident through the provision of translations which were "gratuitously presented" to Taylor (Report of the Tenth Meeting of the British Association for the Advancement of Science 1841). Those given to the committee or "communicated" by Edward Sabine were likely to have been translated by his wife Elizabeth, who was well known and highly regarded for her translation work. For example, when Humboldt asked Joseph Hooker to recommend a translator for Kosmos, he recommended Elizabeth Sabine, on the basis of her well-received translation of the accounts of Wrangel's expeditions; Humboldt was very pleased with the recommendation and requested that Hooker approach Sabine (Hooker 1845). When John Herschel (1857:359-60) favourably reviewed the English translation of Humboldt's Kosmos, he did so in the full knowledge that Elizabeth was the "translatress", although her input is indirectly acknowledged on the title page only in so far as it says "translated under the superintendence of Edward Sabine".

It was not unusual for women's translation work to be published without attribution, as in the case of Sarah Taylor, or with attribution to their husbands, as in the case of Elizabeth Sabine (Brück 2009:101). However, Sabine's case shows that visibility on the title page, and other types of paratextual visibility, are a rather crude measure or indicator of the visibility of the translator. Brück (2009:103) quotes a letter by William Rowan Hamilton written in 1843 referring to the Sabines, whom he had known for many years as friends. Hamilton describes Elizabeth as "rather a learned lady" who "translated many foreign, especially German, papers for Taylor's Memoirs, having no children to occupy her otherwise". Healy's (2004) brief portrait of her as part of a doctoral thesis also argues that Elizabeth Sabine, though largely invisible today, enjoyed a considerably higher profile 
during her life, even if this profile was established through her husband's position and connections and her participation in his geological expeditions. ${ }^{11}$ As noted above, Sabine's translations for Scientific Memoirs were "gratuitously presented" and, since none of the funds which had been made available to the relevant committee of the British Association were expended on them, it is clear that Elizabeth received no payment for her work.

The extent of the translation activities that helped to make up five volumes of Scientific Memoirs indicates that important contributions were made by various people who volunteered their expertise and services. In the next section, possible motivations for these volunteer translation (and revising and publishing) services are explored, drawing on studies of impure altruism and the conception of knowledge as a public good.

\section{Altruism, voluntarism and Scientific Memoirs}

Although Taylor was producing a private good, much of his rhetoric in seeking approbation and support for Scientific Memoirs relied on a perception of scientific knowledge disseminated as a public good that would not only benefit the immediate readers but would also contribute to scientific progress, particularly in Britain. In terms of willingness to publish and thus increase the aggregate level of this public good without seeking to make a profit, Taylor's actions can be described as altruistic. Several of the men of science who volunteered to help him in this endeavour, whether by suggesting texts for translation or carrying out translation or revision work, commented on their wish to see the venture succeed and on its importance for British science. Like Taylor, they may have been mindful of the way in which their contribution would increase the public good of scientific knowledge; their actions could then also be described as altruistic. In promising support for Scientific Memoirs, Roderick Murchison of the British Association for the Advancement of Science spoke of the "causes which tend to retard the progress of science", noting that differences of language constituted an "impediment to a free and rapid communication of thought and of experiments" (Report of the Tenth Meeting of the British Association for the Advancement of Science 1841:xiv). The "progress of science" can thus be seen as the altruistic motivation behind the translation of these foreign memoirs. However, as noted above, altruism can be pure or impure. Without seeking to infer motivations from traces of

\footnotetext{
${ }^{11}$ Although Healy's brief portrait focuses specifically on Sabine's translation work, it makes no mention of her translations for Scientific Memoirs. Healy mentions Gauss's seminal Allgemeine Theorie des Erdmagnetismus (General Theory of Terrestrial Magnetism) but admits that she has no details of the circumstances of its publication (Healy 2004:275-76). It was, in fact, published in Volume 2 of Scientific Memoirs.
} 
behaviour, it is useful to consider some of the motivations commonly associated with impure altruism and the extent to which they could have had a bearing in this case.

Haruvy et al. (2003) examined software programmers' motivations for contributing their expertise to open source software developments without receiving any financial reward (see also McDonough Dolmaya, this volume). Open source software is designed to be made freely available for others to use and develop further, although it is possible for companies to use free open source software in ways that enable them to charge for it, hence the distinction between FOSS and COSS - free and commercial open source software. Warm glow is considered the main motivation for the programmers' behaviour. However, the notion of fairness is also seen to play an important role. Programmers perceive the software as a public good, and become less willing to contribute to its development as a company seeks to increase their profits from a product (Haruvy et al. 2003). The fairness factor may also be applicable in the Scientific Memoirs case, in addition to the possibility of warm glow motivation. It was well publicized by Taylor that he was not expecting to make a profit from the publication, that he simply wished to cover his costs; it could be argued that, like the open source software programmers, those translators who volunteered their services might have been less willing to do so if Taylor were seen to be profiting substantially from their labours.

Behaviour may also be motivated by a mix of intrinsic, extrinsic and reputational motivations that will vary across individuals and contexts (Bénabou and Tirole 2006). Reputational concerns pertain to both the image that we wish to convey to others as well as the extent to which our behaviour fits our own self-image. Reputational benefits thus require the act of volunteering or giving to be made publicly known, as is often the case with donations to charitable causes, resulting in 'prestige' for the donor (Harbaugh 1998:272). In the case of Scientific Memoirs, Taylor produced several texts - advertisements (1841a), notices, prefaces (1852a), published lists of subscribers - which acted as mechanisms for signalling donors. While this may have been one means by which he could express his gratitude for assistance rendered, this kind of public acknowledgement could also contribute to a person's social standing or reputation. It is possible that the men of science were motivated by their desire to be seen to contribute, in various ways, to the venture. For example, in a letter to Taylor, James MacCullagh (1837) bemoaned the fact that his name had not appeared on a published list of subscribers, even though he had been one of the first to subscribe. However, those (like John Richardson) who contributed revisions to Scientific Memoirs but asked not to be acknowledged may also have been motivated by reputational concerns. Too much overt signalling can deter donors who do not wish to be seen as purely 
image-motivated (Bénabou and Tirole 2006:1664). Alternatively, such donors may have been seeking to protect their reputation by ensuring that their revisions were not attributed, in order to shield them from public scrutiny or assessment. Rewards may also be rejected to ensure that a good deed is not deemed to be materially motivated (ibid.:1669); this could account for Hobson's pre-emptive rejection of any pecuniary reward for his translation work.

Taylor's personal and professional standing is highly relevant in any consideration of the social esteem that could be garnered by being visibly associated with Scientific Memoirs. He was one of the most successful commercial scientific publishers at the time and held offices in numerous learned societies. As he himself outlined in evidence to a parliamentary select committee, he offered a central point or node, facilitating or enabling communication between men of science (First Report from the Select Committee of the House of Commons on Postage; together with the Minutes of Evidence and Appendix 1838). Association with him and his publications would have provided access to personal and professional networks, which in turn would have entailed reputational benefits. Moreover, it was noted above that translating was one of the few ways in which women could participate in scientific activities in a socially acceptable and accepted way. Elizabeth Sabine would also likely have garnered social esteem and reputational benefit through her translation work, despite being invisible on title pages. Her provision of translations for Scientific Memoirs may well have contributed to establishing or maintaining that status.

Lipford and Yandle (2009) focus on the interdependent utility of voluntarism in their study of volunteer rates in the US states. They found that volunteer activity within a community is higher when race, language and income are fairly homogenous; people give their time and expertise when they are able to identify the prospective benefits but also to identify with the prospective beneficiaries. Linked to this is another suggested motivation for donation, namely that donors may feel a degree of responsibility for supporting services they themselves also use (Kingma and McClelland 1994:67). These 'donations for use' are studied by Kingma and McClelland in the context of public radio, where a correlation is established between donations to radio stations and time spent listening to them. Given the specialist nature of Scientific Memoirs, it is not surprising that there was a high degree of homogeneity among the group of men who gave their services to the journal, obviously in their shared language but also in their professional and social status. It is also likely that they read the journal. Though it is not possible to examine whether greater use correlated with greater voluntary contributions, there is certainly a sense in the correspondence that those who assisted Taylor in the publication also valued it highly, and archival material confirms that 
most of those listed by Taylor as providing assistance were subscribers. By contrast, the exclusion of women from the professionalization of science at that time means that both of these motivations for volunteering would have been less applicable to them. Firstly, women translators, unlike their male counterparts, were not benefiting from the journal and may therefore have felt no sense of responsibility towards it. Secondly, no women's names featured on the published list of subscribers to Scientific Memoirs; hence, women translators, unlike their male counterparts, may not have identified particularly strongly with the exclusively male beneficiaries.

Other factors discussed in relation to benefits of impure altruism include gaining a degree of influence over the organization to which the donor gives, particularly when time, rather than money, is donated (Kingma and McClelland 1994:66). This may be an important factor in the case of Scientific Memoirs, in that men of science generally proposed texts which were close to their own research interests, thus giving visibility to their own areas of expertise and boosting the profile of their research. For example, the texts translated by Elizabeth Sabine, presumed to have been chosen by her or Edward Sabine, were focused on his area of study, geomagnetism, and indeed drew on some of his work.

Simply being asked has been found to be an important factor in donating and volunteering; people are more likely to give if they are asked to do so (Freeman 1997:165, Andreoni and Rao 2011:517). Taylor can therefore be seen to be improving his chance of receiving donations of translations and other assistance by asking for them, which he did privately through personal correspondence, as well as publicly in advertisements and notices, and by appealing to the British Association for the Advancement of Science for their support. Freeman (1997:164) hypothesizes two factors that influence whether people accede to a request to volunteer. They are more likely to do so, firstly, if they value the activity to which they will be contributing and, secondly, if there is some 'social pressure' attached to the request, i.e. if it comes from friends and family rather than strangers. Freeman also notes that people are more likely to volunteer if the benefits of their work will be experienced by friends or family. Although we have some record of Taylor's requests for assistance, there are other records of requests we cannot trace, but we might assume that Edward Sabine, having promised support to Taylor via the British Association, then asked Elizabeth Sabine to translate the texts that he wished to see published.

\section{Conclusion}


Recent studies of pure and impure altruism from behavioural economics support the view that people may have volunteered their services to Taylor and Scientific Memoirs altruistically, in both pure and impure senses. On the one hand, they may have been motivated altruistically by the wish to increase the public good of scientific knowledge. On the other hand, they may have wished to gain some utility from their participation in this venture. Such benefits could have included the internal sense of satisfaction - the warm glow - derived from helping. The volunteers would have benefited by having their self-esteem or their social esteem and prestige boosted, particularly when their unrecompensed assistance was acknowledged publicly or when others learned of it in some other way. Many of those who volunteered services were also likely consumers of the end product, i.e. readers/subscribers of the journal. Their willingness to volunteer can further be viewed as reflecting a sense of responsibility to support the services they valued, and a sense of identity with those who shared their interests in and need for the journal and the knowledge it disseminated. Finally, Taylor's direct requests for assistance, as well as his regular acknowledgements of help received, may have increased fellow scientists' willingness to volunteer. Although they played a less visible role than the men in the scientific community at the time, it seems possible that the women involved may have garnered similar benefits from their volunteer activities.

This paper has not sought to provide a comprehensive account of factors that may motivate altruistic behaviour, nor has it claimed to be able to discern motivation for activities which can themselves only be studied from documentary traces like those exemplified above. The main contribution of the paper lies, rather, in its proposal that concepts of altruism developed in economic studies of volunteering and donating may be usefully applied to volunteer translation and interpreting activity; to my knowledge, no economist has undertaken an analysis of volunteer translation or interpreting, and translation scholars have only begun to give this activity their serious attention. ${ }^{12}$ This is a topic of increasing scholarly interest, given the perceived increase in volunteer translation and interpreting in a wide variety of contexts worldwide. The case study of Scientific Memoirs exemplifies one way in

\footnotetext{
${ }^{12}$ Baker (2012) draws on Melucci's work on the sociological category of 'altruistic action', defined as "collective, purposive, and organized social altruism" (Melucci 1996:168). Like volunteering, the concept of altruism is approached by economists and sociologists from different perspectives. This paper takes a more economically oriented view than Melucci or Baker, who do not distinguish between pure and impure altruism or consider types of utility or benefit derived by volunteers from volunteering.
} 
which the topic can be addressed. The study also sheds some light on nineteenth-century publishing of science and the role of translators and others in that endeavour.

Secondly, the introduction of the concept of altruism to translation studies makes clear the complexity of any volunteer activity, considering the multifarious and overlapping factors that may motivate apparently altruistic behaviour. While it is difficult to account for the mix of intrinsic and extrinsic motivations in theoretical terms, and more difficult still to provide empirical verification, it is nonetheless worth exploring why people (whether they belong to the translation or interpreting profession or not) give their translation or interpreting services without remuneration. Attributing motivations to behaviour is methodologically challenging, particularly when studying actions in the past. Economists conduct much of their research on altruism in experimental settings, but it is also possible to use questionnaire data and psychometric testing to infer attitudes to altruism; there is scope to consider how such survey methods could be employed in studies of present-day volunteer translators. As noted above, O’Brien and Schäler's (2010) study of translators who volunteer for the Rosetta Foundation provides an example of how questionnaire data has been used to explore issues of motivation (see McDonough Dolmaya, this volume, for a similar study). Such surveys provide a useful starting point but may need to be supplemented by additional research tools and methods to assist researchers in relating stated motivations to data on attitudes, values and personality traits. Methodologies may require yet further refinement to take account of cross-cultural variation in concepts of social obligation within a group of multilingual and multicultural volunteer translators.

Finally, applying the concept of a public good in the context of one particular volunteer translation activity enables us to draw useful parallels with a wide range of other contexts in which translations and interpretations are volunteered, thus underlining the relevance of this historical case for other studies of volunteer translation and interpreting today. Contexts in which translation and interpreting are volunteered include humanitarian aid, social activism, and website and software localization. And if open source software or the internet (Steyaert and Gould 2009) are considered as public goods, then an exploration of pure and impure altruism is as valid for those contexts as for the publishing of a scientific journal where the public good consists of knowledge. This framework may thus be applied to studies of volunteer translation for Facebook, Twitter, GNU, Wikipedia, etc.

It is not only of interest to consider why people volunteer translations but how organizations succeed in mobilizing translators and interpreters to work on a voluntary basis to support the organizations' activities. What motivating factors are highlighted by the 
organizations and what does this reveal about their perceptions of those being targeted as potential volunteer translators? Organizations are likely to consider such issues when they 'recruit' translators, but translation researchers have not yet studied how this recruitment takes place or what it suggests about the motivations of volunteer translators. ${ }^{13}$ Such questions may be of particular interest where an organization's activities are commercial, or where an organization does not expect to procure other important services free of charge, or where it may seek to profit from volunteer translation activity. ${ }^{14}$ In relation to these and many other situations involving volunteer translation or interpreting, there is thus considerable scope for translation scholars and others to contribute to a much greater understanding of the socio-economic complexities of that activity, including the altruism - pure or impure reflected in the behaviour of those who translate and interpret.

\section{MAEVE OLOHAN}

Centre for Translation and Intercultural Studies, School of Arts, Languages and Cultures, University of Manchester, Oxford Road, M13 9PL, Manchester, UK.

Maeve.Olohan@manchester.ac.uk

\section{References}

Andreoni, James (1988) 'Privately Provided Public Goods in a Large Economy: The Limits of Altruism', Journal of Public Economics 35(1): 57-73.

----- (1989) 'Giving with Impure Altruism: Applications to Charity and Ricardian Equivalence', Journal of Political Economy 97(6): 1447-58.

------ (1990) 'Impure Altruism and Donations to Public Goods: A Theory of Warm-Glow Giving', The Economic Journal 100(401): 464-77.

------ and Justin M. Rao (2011) 'The Power of Asking: How Communication Affects Selfishness, Empathy, and Altruism', Journal of Public Economics 95(78): 513-20.

Arena, Marika and Kim K. Jeppesen (2010) 'The Jurisdiction of Internal Auditing and the Quest for Professionalization: The Danish Case', International Journal of Auditing 14(2): 111-29.

Ashraf, Nava, Colin F. Camerer and George Loewenstein (2005) 'Adam Smith, Behavioral Economist', Journal of Economic Perspectives 19(3): 131-45.

Baker, Mona (2010) 'Translation and Activism: Emerging Patterns of Narrative Community', in Maria Tymoczko (ed.) Translation, Resistance, Activism, Amherst, MA: University of Massachusetts Press, 23-41.

----- (2012) 'Translation as an Alternative Space for Political Action', Social Movement Studies, iFirst online, DOI:10.1080/14742837.2012.685624 (last accessed 25 June 2012).

\footnotetext{
${ }^{13}$ A related issue is highlighted by Baker (2010) in a discussion of how a commercial translation company commodifies volunteer, humanitarian translation to achieve reputational benefits.

${ }^{14}$ The filing of a patent application by Facebook (Losse et al. 2009) for 'Community Translation on a Social Network' raises interesting issues in this regard.
} 
Bazerman, Charles (1988) Shaping Written Knowledge: The Genre and Activity of the Experimental Article in Science, Madison, WI: University of Wisconsin Press.

Bénabou, Roland and Jean Tirole (2006) 'Incentives and Social Behavior', American Economic Review 96(5): 1652-78.

Bennett, Karen (2007) 'Galileo's Revenge: Ways of Construing Knowledge and Translation Strategies in the Era of Globalization', Social Semiotics 17(2): 171-93.

Black, John, Nigar Hashimzade and Gareth Myles (2009) A Dictionary of Economics, Oxford: Oxford University Press. Available at: http://www.oxfordreference.com (last accessed 13 March 2012).

Boéri, Julie and Carol Maier (eds) (2010) Translation/Interpreting and Social Activism, Manchester: St Jerome Publishing.

Brayley, Edward (1836) Letter to Richard Taylor, 26 October 1836, Taylor and Francis Archive, St Bride Library.

Brock, William H. and Arthur J. Meadows (1998) The Lamp of Learning: Two Centuries of Publishing at Taylor \& Francis, 2nd edition, London: Taylor \& Francis.

Brück, Mary (2009) Women in Early British and Irish Astronomy: Stars and Satellites, Dordrecht: Springer.

Camerer, Colin F. and George Loewenstein (2004) 'Behavioral Economics: Past, Present, Future', in Colin F. Camerer, George Loewenstein and Matthew Rabin (eds) Advances in Behavioral Economics, Princeton, NJ: Princeton University Press, 3-51.

Cappellari, Lorenzo, Paolo Ghinetti and Gilberto Turati (2011) 'On Time and Money Donations', Journal of Socio-Economics 40(6): 853-67.

European Master's in Translation (EMT) Network (2009) European Commission DirectorateGeneral for Translation. Available at:

http://ec.europa.eu/dgs/translation/programmes/emt/index_en.htm (last accessed 13 March 2012).

Fara, Patricia (2006) 'Women or Just Good Scientists?', Nature 444: 548.

Ferguson, Eamonn, Femke Atsma, Wim de Kort and Ingrid Veldhuizen (2012) 'Exploring the Pattern of Blood Donor Beliefs in First-time, Novice, and Experienced Donors: Differentiating Reluctant Altruism, Pure Altruism, and Warm Glow', Transfusion 52(2): 343-55.

First Report from the Select Committee of the House of Commons on Postage; together with the Minutes of Evidence and Appendix (1838) in The Sessional Papers Printed by Order of The House of Lords, or Presented by Royal Command, in the Session 183738 , London.

Forbes, James D. (1836) Letter to Richard Taylor, 14 April 1836, Taylor and Francis Archive, St Bride Library.

Francis, William (1843) Letter to Richard Taylor, 14 July 1843, Taylor and Francis Archive, St Bride Library.

Freeman, Richard B. (1997) 'Working for Nothing: The Supply of Volunteer Labor', Journal of Labor Economics 15(1): 140-66.

Fuegi, John and Jo Francis (2003) 'Lovelace \& Babbage and the Creation of the 1843 "Notes", IEEE Annals of the History of Computing 25(4): 16-26.

Graham, Keith (2004) 'Altruism, Self-interest and the Indistinctness of Persons', in Jonathan Seglow (ed.) The Ethics of Altruism, London: Frank Cass, 51-70.

Guagnano, Gregory A. (2001) 'Altruism and Market-Like Behavior: An Analysis of Willingness to Pay for Recycled Paper Products', Population and Environment 22(4): 425-38. 
Gutas, Dimitri (1998) Greek Thought, Arabic Culture: The Graeco-Arabic Translation Movement in Baghdad and Early Abbāsid Society (2nd-4th/8th-10th Centuries), London \& New York: Routledge.

Haines, Catharine M.C. (2001) International Women in Science: a Biographical Dictionary to 1950, Santa Barbara, CA: ABC-CLIO.

Handy, Femida and Laurie Mook (2011) 'Volunteering and Volunteers: Benefit-Cost Analyses', Research on Social Work Practice 21(4): 412-20.

Handy, Femida, Ram A. Cnaan, Jeffrey L. Brudney, Ugo Ascoli, Lucas C. M. P. Meijs and Shree Ranade (2000) 'Public Perception of "Who Is a Volunteer": An Examination of the Net-Cost Approach from a Cross-Cultural Perspective', Voluntas: International Journal of Voluntary and Nonprofit Organizations 11(1): 45-65.

Harbaugh, William T. (1998) 'What Do Donations Buy? A Model of Philanthropy Based on Prestige and Warm Glow', Journal of Public Economics 67(2): 269-84.

Haruvy, Ernan, Ashutosh Prasad and Suresh P. Sethi (2003) 'Harvesting Altruism in Opensource Software Development', Journal of Optimization Theory and Applications 118(2): 381-416.

Healy, Michele (2004) The Cachet of the "Invisible" Translator: Englishwomen Translating Science (1650-1850), unpublished PhD thesis, Ottawa: University of Ottawa.

Henry, Joseph (1837) 'The Influence of a Spiral Conductor in Increasing the Intensity of Electricity from a Galvanic Arrangement of a Single Pair', in Richard Taylor (ed.) Scientific Memoirs, Selected from the Transactions of Foreign Academies of Science and Learned Societies, and from Foreign Journals, London: Richard \& John E. Taylor, 540-47.

Herschel, John (1857) 'Humboldt's Kosmos (reprinted from The Edinburgh Review for January, 1848)', in Essays from the Edinburgh and Quarterly Reviews, With Addresses and Other Pieces, by John Herschel, London: Longman, Brown, Green, Longman \& Roberts, 257-364.

Hobson, Alfred W. (1847) Letter to Richard Taylor, 4 February 1847, Taylor and Francis Archive, St Bride Library.

Hooker, Joseph (1845) Letter to Charles Darwin, July 1845, Darwin Correspondence Database. Available at: http://www.darwinproject.ac.uk/entry-884 (last accessed 13 March 2012).

Inkster, Ian (1991) Science and Technology in History: An Approach to Industrial Development, Basingstoke: Macmillan.

Jardine, Nick (2000) The Scenes of Inquiry: On the Reality of Questions in the Sciences, 2nd edition, Oxford: Oxford University Press.

Kingma, Bruce R. and Robert McClelland (1994) 'Public Radio Stations Are Really, Really Not Public Goods: Charitable Contributions and Impure Altruism', Annals of Public and Cooperative Economics 66(1): 65-76.

Knight, David (1986) The Age of Science: The Scientific World-View in the Nineteenth Century, Oxford: Basil Blackwell.

----- (2004) Science and Spirituality: The Volatile Connection, London \& New York: Routledge.

(2007) 'The Spiritual in the Material', in Robert Michael Brain, Robert S. Cohen and

Ole Knudsen (eds) Hans Christian Ørsted and the Romantic Legacy in Science,

Dordrecht: Springer Netherlands, 417-32.

Latour, Bruno and Steve Woolgar (1986) Laboratory Life: The Construction of Scientific Facts, 2nd edition, Princeton, NJ: Princeton University Press.

Lipford, Jody W. and Bruce Yandle (2009) 'The Determinants of Purposeful Voluntarism', Journal of Socio-Economics 38(1): 72-79. 
Losse, Katherine, Ting Yin Kwan, Javier Oliván-López, Stephen M. Grimm, Rebekah Cox, Marcel Laverdet, Chad Little, Nicolas Vera, Yisham Wong, Christopher Putnam (2009) 'Community Translation on a Social Network', US Patent Application, filed 5 December 2008, US Patent \& Trademark Office.

Lusk, Jayson L., Tomas Nilsson and Ken Foster (2006) 'Public Preferences and Private Choices: Effect of Altruism and Free Riding on Demand for Environmentally Certified Pork', Environmental and Resource Economics 36(4): 499-521.

MacCullagh, James (1837) Letter to Richard Taylor, n.d. 1837, Taylor and Francis Archive, St Bride Library.

Melucci, Alberto (1996) Challenging Codes: Collective Action in the Information Age, First Edition, Cambridge: Cambridge University Press.

Moll, Jorge, Frank Krueger, Roland Zahn, Matteo Pardini, Ricardo de Oliveira-Souza, and Jordan Grafman (2006) 'Human Fronto-Mesolimbic Networks Guide Decisions about Charitable Donation', Proceedings of the National Academy of Sciences 103(42): 15623-28.

Montgomery, Scott L. (2000) Science in Translation: Movements of Knowledge Through Cultures and Time, Chicago: University of Chicago Press.

Morado Vásquez, Lucía, Dimitra Anastasiou, Chris Exton and Ian O’Keefe (2011) 'Web 2.0 and Localisation', paper presented at the First International Workshop on Social Media Engagement, 29 March 2011, Hyderabad, India. Available at: http://wwwhome.math.utwente.nl/ volkovichyv/SOME2011papers/paper6.pdf (last accessed 13 March 2012).

O’Brien, Sharon and Reinhard Schäler (2010) 'Next Generation Translation and Localization: Users Are Taking Charge', paper presented at Translating and the Computer 32, ASLIB, London. Available at: http://doras.dcu.ie/16695/1/Paper_6.pdf (last accessed 13 March 2012).

Olohan, Maeve and Myriam Salama-Carr (eds) (2011) Science in Translation, Special Issue of The Translator 17(2).

Optimale (n.d.) 'Optimising Translator Training', Optimale Website. Available at: http://www.translator-training.eu/ (last accessed 13 March 2012).

Pérez González, Luis (2010) “"Ad-hocracies” of Translation Activities in the Blogosphere: A Genealogical Case Study', in Mona Baker, Maeve Olohan and María Calzada Pérez (eds) Text and Context: Essays on Translation and Interpreting in Honour of Ian Mason, Manchester: St Jerome Publishing, 259-87.

Rashed, Roshdi (2006) 'Greek into Arabic: Transmission and Translation', in James Edward Montgomery (ed.) Arabic Theology, Arabic Philosophy: From the Many to the One. Essays in Celebration of Richard M. Frank, Louvain: Peeters Publishers, 157-98.

Report of the Tenth Meeting of the British Association for the Advancement of Science (1841) London: John Murray.

Richardson, John (1846) Letter to Richard Taylor, 13 July 1846, Taylor and Francis Archive, St Bride Library.

Richardson, Thomas (1841) Letter to Richard Taylor, 3 February 1841, Taylor and Francis Archive, St Bride Library.

Royal Society (n.d.) 'Gender Profile of the Fellowship', Royal Society Website. Available at: http://royalsociety.org (last accessed 13 July 2010).

Sabine, Edward (1858) 'Editor's Preface', in Cosmos: Sketch of a Physical Description of the Universe, Vol. IV, Part I, by Alexander von Humboldt, trans. by Elisabeth Sabine, London: Longman, Brown, Green, Longmans \& Roberts; John Murray. 
Santoyo, Julio-César (2006) 'Blank Spaces in the History of Translation', in Georges L.

Bastin and Paul F. Bandia (eds) Charting the Future of Translation History, Ottawa: University of Ottawa Press, 11-40.

Shields, Rachel (2010) 'Women in Science: Pioneers Blaze Path for Others', The Independent, 21 March 2010. Available at:

http://www.independent.co.uk/news/science/women-in-science-pioneers-blaze-pathfor-others-1924794.html (last accessed 13 March 2012).

Snyder, Mark, and Allen M. Omoto (2008) 'Volunteerism: Social Issues Perspectives and Social Policy Implications', Social Issues and Policy Review 2(1): 1-36.

Steyaert, Jan and Nick Gould (2009) 'Social Work and the Changing Face of the Digital Divide', British Journal of Social Work 39(4): 740-53.

Stiglitz, Joseph E. (1999) 'Knowledge as a Global Public Good', in Inge Kaul, Isabelle Grunberg and Marc A. Stern (eds) Global Public Goods: International Cooperation in the 21st Century, New York: Oxford University Press, 308-25.

Strickland, Hugh (1840) Letter to Richard Taylor, 13 August 1840, Taylor and Francis Archive, St Bride Library.

Taylor, Richard (1837a) 'Notice Relative to the Publication of the Scientific Memoirs', Philosophical Magazine 10(59): 81-84.

- (1837b) 'Preface to the First Volume', in Richard Taylor (ed.) Scientific Memoirs, Selected from the Transactions of Foreign Academies of Science and Learned Societies, and from Foreign Journals, London: Richard \& John E. Taylor.

(1841a) 'Advertisement to the Seventh Part', in Richard Taylor (ed.) Scientific Memoirs, Selected from the Transactions of Foreign Academies of Science and Learned Societies, and from Foreign Journals, London: Richard \& John E. Taylor.

(1852a) 'Preface to the Fifth Volume', in Richard Taylor (ed.) Scientific Memoirs,

Selected from the Transactions of Foreign Academies of Science and Learned Societies, and from Foreign Journals, London: Richard \& John E. Taylor.

Taylor, Richard (ed.) (1837c) Scientific Memoirs, Selected from the Transactions of Foreign Academies of Science and Learned Societies, and from Foreign Journals, London: Richard \& John E. Taylor.

------ (1841b) Scientific Memoirs, Selected from the Transactions of Foreign Academies of Science and Learned Societies, and from Foreign Journals, London: Richard \& John E. Taylor.

(1843) Scientific Memoirs, Selected from the Transactions of Foreign Academies of Science and Learned Societies, and from Foreign Journals, London: Richard \& John E. Taylor.

- (1846) Scientific Memoirs, Selected from the Transactions of Foreign Academies of Science and Learned Societies, and from Foreign Journals, London: Richard \& John E. Taylor.

(1852b) Scientific Memoirs, Selected from the Transactions of Foreign Academies of Science and Learned Societies, and from Foreign Journals, London: Richard \& John E. Taylor.

Topham, Jonathan R. (2004) 'Technicians of Print and the Making of Natural Knowledge', Studies in History and Philosophy of Science 35(2): 391-400.

Wilson, John (2000) 'Volunteering', Annual Review of Sociology 26: 215-40.

Winter, Alison (1998) 'A Calculus of Suffering: Ada Lovelace and the Bodily Constraints on Women's Knowledge in Early Victorian England', in Steven Shapin and Christopher Lawrence (eds) Science Incarnate: Historical Embodiments of Natural Knowledge, Chicago: University of Chicago Press, 202-39. 
Wright, David (2000) Translating Science: The Transmission of Western Chemistry into Late Imperial China, 1840-1900, Leiden: Brill.

Yeo, Richard (1993) Defining Science: William Whewell, Natural Knowledge and Public

Debate in Early Victorian Britain, Cambridge: Cambridge University Press. 